1. Зоря Т. М. Соціально-економічні наслідки міжнародної трудової міграції. Соціально-трудові відносини: теорія та практика. 2012. № 2(4). С. 113-117

2. Ломакін В.К. Світова економіка: підручник для вузів. М.: ЮНИТИ-ДАНА, 2003. 317с.

3. Роменчак О. Визначення та класифікація міграцій: наближення до операційних понять. Політичний менеджмент. 2006. № 2. С. 139

4. П’ятковська О. Класифікація видів міжнародної трудової міграції: окреслення операційних понять. Галищький економічний вісник. 2011. №1(30). С. 30-34

5. Козак Ю.Г. Міжнародна економіка: підруч. для студ. вищ. навч. закл. Київ: Центр учбової літератури, 2018. - 560 с.

6. Солонінко К.С. Міжнародна економіка: навч.посіб. Київ: Кондор, 2018 р. 380 с.

7. Орловська Ю.В., Рєліна І.С. Міграція висококваліфікованих кадрів з України в сучасних умовах. URL: http://esteticamente.ru/portal/soc_gum/pips/2014_2/index.htm (дата звернення 15.10.2020).

8. Ткаченко М.Ф. Глобальные вызовы для мирового рынка. Мировая экономика и международные отношения. 2011. №9. С.67.

9. Онікієнко В.В. Ринок праці та соціальний захист населення України. Інститут демографії та соціальних досліджень імені М.В. Птухи НАН України. Київ. 2014. 454 с.

\title{
References
}

1. Zoria, T.M. "Socio-economic consequences of international labor migration." Social and labor relations: theory and practice, no. 2 (4), 2012, pp. 113-117

2. Lomakin, V.K. World Economy: a textbook for universities. Moscow, UNITI-DANA, 2003.

3. Romenchak, O. "Definition and classification of migrations: approximation to operational concepts." Political management, no. 2, 2006, pp. 139.

4. Pyatkovska, O. "Classification of types of international labor migration: delineation of operational concepts." Galician Economic Bulletin, no.1(30), 2011, pp. 30-34.

5. Kozak, Yu.G. International economics: textbook. for students. Kyiv, Center for Educational Literature, 2018.

6. Soloninko, K.S. International Economics: textbook. Kyiv, Condor, 2018.

7. Orlovska, Y.V., and I.E.Relina, "Migration of highly qualified personnel from Ukraine in modern conditions." Esteticamente, esteticamente.ru/portal/soc_gum/pips/2014_2/index.htm Accessed: 15.10.2020.

8. Tkachenko, M.F. "Global challenges for the world market." World economy and international relations, no.9, 2011, pp. 67.

9. Onikienko, V.V. Labor market and social protection of the population of Ukraine. Kiev, Institute of Demography and Social Research of the National Academy of Sciences of Ukraine. 2014.

УДК 338:339.7

doi: 10.15330/apred.2.16.36-44

\section{ЗМІНИ У СИСТЕМІ ОПОДАТКУВАННЯ ТУРИСТИЧНОГО БІЗНЕСУ У КРАЇНАХ ЄВРОПЕЙСЬКОГО СОЮЗУ У ПЕРІОД СВІТОВОї ПАНДЕМІї COVID-19}

\author{
Хмельницький національний університет, Міністерство \\ освіти і науки України, \\ кафедра міжнародних економічних відносин, \\ вул. Інститутська 11, корп. 3, м. Хмельницький, \\ 29016, Україна, \\ тел.: 0673541589, \\ e-mail: slavamudra0718@gmail.com
}


Актуальні проблеми розвитку економіки регіону. Вип 16. T.2

Анотація. Стаття спрямована на дослідження механізмів податкової політики країн Європейського Союзу (далі - ЄC) 3 акцентуванням уваги на підходах до оподаткування туристичного бізнесу до початку та протягом 2020 року. Необхідністю проведених досліджень $\epsilon$ зміни у податковому та фінансовому законодавстві у країнах $\mathrm{CC}$ під впливом світової пандемії COVID-19. Відображено основні аспекти оподаткування та підходи до реалізації податкової політики у країнах $\mathrm{CC} з$ найвищим рівнем туристичної привабливості та кількість відвідувань туристами.

Відображено статистичні дані, які демонструють міру зайнятості у туристичному бізнесі та впливу обсягів туристичного бізнесу на зростання ВВП ЄС загалом та в окремих країнах зокрема. Показано відсоткове співвідношення податкових сплат за рівнями податкової ієрархії $\mathrm{EC}$, що доводить необхідність підтримки туризму як важливої сфери для працевлаштування та підвищення привабливості туристичних країн та окремих локацій для зростання внутрішніх та зовнішніх туристичних потоків.

Проаналізовано фінансові та податкові механізми та інструменти, які запроваджені окремими країнами $\mathrm{CC}$ для підтримки підприємств, що зазнали збитків при карантинних умовах та обмеженні своєї діяльності у період світової пандемії. Акцентовано на змінах у загальній політиці ЄС щодо надання податкової інформації країнами-членами щодо резидентів та нерезидентів у бізнес-середовищі та туристичній сфері зокрема.

Ключові слова: податкова політика, туристична сфера, світова пандемія.

\title{
CHANGES IN THE TAX SYSTEM OF THE TOURISM IN THE EUROPEAN UNION COUNTRIES IN TIME OF THE WORLD PANDEMIC
}

\author{
Khmelnytsky National University, \\ Ministry of Education and Science of Ukraine, \\ Department of International Economic Relations, \\ Institutska str.11 bld. 3, Khmelnytsky, \\ 29016, Ukraine, \\ tel.: 0673541589, \\ e-mail: slavamudra0718@gmail.com
}

\begin{abstract}
The article is aimed on studying the mechanisms of tax policy of the European Union (the EU) with a focus on approaches to taxation of the tourism business before and during 2020. The need for research is changes in tax and financial legislation in the EU under the influence of the global pandemic COVID-19. The main aspects of taxation and approaches is to the implementation of tax policy in the EU countries with the highest criterion of tourist attractiveness and the number of visits.

Statistics are presented, which show the degree of employment in the tourism business and the impact of tourism business on EU GDP growth in general and in individual countries in particular. The percentage of tax payments with the levels of government is shown, which proves the need to support tourism as an important business unit for employment in the tourism sector and maintain the attractiveness of tourist countries and locations for the growth of domestic and foreign tourist flows.

The financial and tax mechanisms and instruments are introduced by individual EU countries to support enterprises that have suffered losses under quarantine conditions and limit their activities during the global pandemic are analyzed. Emphasis is placed on changes in the general EU policy on the provision of tax information by member states on residents and non-residents in the business environment and tourism in particular.
\end{abstract}

Key words: tax policy, tourism, global pandemic.

Вступ. Оподаткування туристичного бізнесу у країнах Європейського Союзу вирізняється цілим рядом специфічних ознак, зважаючи на те, що туристичний бізнес на початку 2020 року був одним із найприбутковіших видів економічної діяльності. Галузь туристичних послуг функціонує у тісному взаємозв'язку з іншими галузями, 
такими як транспорт, охорона навколишнього середовища, регіональне планування, енергетика, торгівля, бізнес та інформаційні технології, ін. Такий взаємозв'язок вимагає виваженого та прорахованого податкового механізму, який повинен бути націлений не лише на оптимальне оподаткування, а й на активне заохочення до розвитку галузі загалом. Дослідження податкової політики Європейського Союзу у економіко-правових та соціальних аспектах здійснено такими вітчизняними науковцями як: Атаманчук Н.I., Іванов Ю.Б., Л. Касьяненко, А. Крисоватий, А. Мельник, С. Владика, В. Чайка, М. Ярош, ін. Проте, пандемія 2020 року, яка спричинила стагнацію розвитку туристичного бізнесу у світі, змусила переглянути окремі аспекти податкової політики ву більшості країн світу і в країнах СС зокрема. Наслідки впливу пандемії на загальні економічні показники досліджує та прогнозує цілий ряд експертів та науковців, проте зміни податкових механізмів, які мають місце у 2020 році залишаються актуальним питанням і є об'єктом дослідження у цій статті.

Постановка завдання. Турбулентні та непередбачені обставини, 3 якими зустрілася сфера туризму у 2020 викликали ряд дискусій, які грунтуються на тих змінах у системі оподаткування, які впроваджують більшість країн Європейського Союзу для основних економічних суб'єктів і туристичної сфери. Зміни у підходах до оподаткування туристичної сфери, які на початку 2020 року стосувалися переважно туристів у частині підвищення туристичного збору, у період пандемії COVID-19 відобразилися на організаторах туристичних послуг загалом. Проблема постала у двох площинах. По-перше, зростаюча протягом десятиліть сфера туризму, яка приносила суттєві доходи як до місцевих бюджетів так і до центрального бюджету СС i потребувала вже у більшості збільшення туристичних зборів для врегулювання кількості туристів та навантаження на визначні туристичні міста та локації. По-друге, епідеміологічна ситуація та ряд карантинних обмежень, які у результаті привели до зростаючої збитковості туристичної галузі, що вимагає не лише скорочення податкових сплат, або їх відтермінування, а й державної підтримки загалом. Тому, грунтуючись на правилах та принципах податкової політики $\mathrm{CC}$, у даній статті поставлено завдання проаналізувати основні зміни податкової політики СС у сфері туризму у 2020 році.

Результати. Загальна стратегія податкової політики $Є C$, яка первісно базувалася на принципах гармонізації, міститься в Повідомленнях Комісії СС від 23 травня 2001 року про «Податкову політику в СС - пріоритети на майбутні годи». У цьому повідомленні Комісія ЄС зазначає, що не існує необхідності гармонізації національних податкових систем держав-членів ЄС. Право вибору системи оподаткування є прерогативою кожної країни - члена СС [5]. Проте за принципами позитивної та негативної інтеграції, які дозволяють координувати рішення ЄС 3 погодженням 3 країнами - учасницями, інстанцією першого порядку залишаться Європейська комісія.

У загальному, податкова політика Європейського союзу відображає собою систему регулювання суспільних відносин, у процесі реалізації інтеграційних процесів i гармонізації національних правових i політичних систем, що здійснюються інститутами і органами Європейського союзу. Забезпечення реалізації загальної податкової політики передбачено Договором про Свропейський Союз (Свобод руху товарів, осіб, послуг і капіталів), недопущення недобросовісної і згубної податкової конкуренції юрисдикцій держав-членів, недопущення податкової дискримінації на внутрішньому ринку, вироблення нових принципів і механізмів усунення подвійного оподаткування, а також забезпечення боротьби з податковими правопорушеннями [1, 2]. Політика ЄС у сфері прямих податків спрямована на те, щоб вирівняти умови конкуренції, забезпечити вільне пересування капіталів і створити сприятливий податковий режим. 
Об’єктом оподаткування є реалізація товарів і послуг на території країн-учасниць Євросоюзу. Платниками податків ПДВ виступають особи, які ведуть економічну діяльність на території ЄС. Попри це, у деяких країнах ЄС досі зберігається подвійна система оподаткування, при якій за внутрішніми операціями компанія сплачує ПДВ до бюджету.

Податкова політика ЄС у сфері туризму стосується комплексної бізнес моделі туристичного бізнесу, яка охоплює такі бізнес-одиниці: туроператори, до яких відносять як представників великих туристичних мереж так і незалежних операторів ринку (сегмент В2C); компанії 3 управління подорожами (Travel Management Companies), які виступають посередниками при організації ділових поїздок i обслуговують переважно корпоративних клієнтів (В2B); туристичні агенти, які виконують посередницькі функції на ринку відпочинку (B2C); компанії, які управляють туристичними потоками у містах та певних локаціях (B2B); компанії, які організовують міжнародні зустрічі, конференції, івенти і працюють на корпоративний сегмент (В2В) [10]. Зважаючи на те, що діяльність всіх зазначених бізнес-одиниць безпосередньо належить до видів електронної комерції, то діяльність цих компаній підлягає регулятивним нормам таких директив як: Директива 1999/93/СС про електронні підписи, Директива 2000/31/СС про електронну комерцію, Директиву 2001/29/СС про інформаційне суспільство, Директиву 97/7/СС про дистанційні продажі [1, с.51].

Для реалізації податкового механізму у країнах $\mathrm{CC}$ консолідується облік наданих послуг бізнес-одиницями туристичного ринку, який здійснюється за однаковим принципом, незалежно від способу отримання ними доходів (націнки, зборів чи комісійних). Загальна сума грошових коштів, сплачених відвідувачами за посередницькі послуги бізнес одиниць туристичного ринку, відповідно до п. 6.50 Міжнародних рекомендацій по статистиці туризму 2008 р. (далі - МРСТ 2008) поділяється на дві частини[3]:

1) Вартість послуг туристичних агенцій чи послуг 3 бронювання: валовий прибуток, отриманий у формі націнки; збори або комісійні платеж;

2) Вартість послуг, що надаються у сфері туризму за участю посередників (дохід постачальника за мінусом комісії, що сплачується постачальнику послуг 3 бронювання).

Трактуючи вище наведені механізми, вартість споживання туристичних послуг являє собою повну ціну, сплачену відвідувачем або будь-ким іншим у його / iii інтересах, 3 врахуванням податку на додану вартість (ПДВ) або податку з продажу, відшкодованого відвідувачам-нерезидентам при виїзді з країни [9].

У країнах $Є С$ ефективно працює консолідована корпоративна податкова база (Consolidated Corporate Tax Base), яка охоплює єдиний набір правил, які компанії, що працюють в СС, могли б використовувати для розрахунку їх оподатковуваного прибутку. Тобто, для обчислення оподатковуваного доходу компанія керується уніфікованою для всіх країн системою, а не окремо діючою у кожній країні. Такі компанії подають одну консолідовану податкову декларацію зі своєї діяльності в ЄС. Консолідовано оподатковуваний прибуток корпоративної групи розподіляється на окремі компанії за простою формулою, щоб кожна держава змогла оподаткувати прибуток компаній в своїй державі за податковою ставкою, яку кожна держава-член обирає. Аналогічно система працює і для туристичних компаній. Якщо туристична компанія $є$ представником міжнародної мережі, то податкова декларація подається одна і консолідована.

Узагальнено туристичні компанії у Свропейському Союзі сплачують до бюджетів всіх рівнів такі види податків:

1) ПДВ за «0» ставкою; 
Актуальні проблеми розвитку економіки регіону. Вип 16. T.2

2) Податок $з$ доходів фізичних осіб та податок на прибуток (корпоративний податок);

3) Податок на нерухомість (якщо є у власності);

4) Податок на дивіденди, ін. [8].

Податкова політика країн ЄС є гнучкою, оскільки враховує стан політичної та економічної кон'юнктури, що відповідно впливає на ставки податків, при цьому розподіл податкових надходжень залишається стабільним протягом тривалого періоду. Ставки ПДВ є стандартними або зниженими i, як правило, підприємства, які надають туристичні та готельні послуги сплачують ПДВ за зниженими ставками або за «0» ставкою.

Податкові платежі, які перераховуються до бюджету СС складають понад 50\% відрахувань (табл.1), тоді як до державних та місцевих бюджетів перераховується близько $15 \%$.

Таблиия 1

\section{Частка податкових надходжень за структурою, \% [7]}

Table 1

The share of tax revenues by structure

\begin{tabular}{|c|c|c|c|c|}
\hline & $\begin{array}{c}\text { Центральний } \\
\text { бюджет ЄС }\end{array}$ & $\begin{array}{c}\text { Бюджети країн- } \\
\text { учасниць }\end{array}$ & $\begin{array}{c}\text { Місцеві } \\
\text { податки }\end{array}$ & $\begin{array}{c}\text { Соціальні } \\
\text { фонди }\end{array}$ \\
\hline СC-28 & 52,424 & 6,469 & 9,693 & 30,883 \\
\hline EC-27 & 46,1 & 7,444 & 10,377 & 35,537 \\
\hline C3-19 & 43,659 & 8,605 & 9,042 & 38,129 \\
\hline
\end{tabular}

Місцеві податки, які становлять близько 10\% від всіх податкових сплат, безпосередньо спрямовані на відновлення та покращення туристичної інфраструктури міст, створення об'єктів туристичної привабливості, ін.

До місцевих податків сфери туризму належать: туристичний збір; податок на прибирання територій; податок на використання комунікацій; ін.

Туристична індустрія $€ С$, яка складається із традиційних постачальників туристичних послуг та споживачів туристичних послуг, налічує 2,3 млн малих та середніх підприємств. У сфері туризму СС працевлаштовано близько 12,3 млн осіб, що становить 5,1\% від загальної зайнятості. У 2014 році кожне 310 підприємств нефінансових галузей $Є С$ належало до туристичної галузі, тоді як у 2019 році - кожне 8 [8]. У 2018 році внесок сектору „подорожі та туризм” до ВВП ЄС складав 3,9\% [10]. Загалом, за період 2015-2019 рр. щорічний приріст туристичних потоків до країн СС складав від 3 до 3,6 \%. Табл. 2.

Таблиия 1

Обсяг туристичних потоків до країн СС за 2015-2019 рр., осіб [7]

Table 2

Arrivals at tourist accommodation establishment 2015-2019

\begin{tabular}{|c|c|c|c|c|c|}
\hline & 2015 & 2016 & 2017 & 2018 & 2019 \\
\hline EC-28 & 331052355 & 346490274 & 374967422 & 392936908 & 407208017 \\
\hline EC-27 & 375326474 & 389959878 & 421718616 & 440606716 & 457377341 \\
\hline E3-19 & 362782965 & 376252434 & 406136912 & 423971703 & 440029285 \\
\hline
\end{tabular}

Зростаючий обсяг туристичних потоків вплинув на ряд рішень окремих країн 3 підвищеною туристичною привабливістю (Франція, Італія, Іспанія, Норвегія, ін.) щодо підвищення ставки туристичного збору, цільове направлення якої було спрямоване на відновлення та збереження екологічного стану. Збільшення ставки туристичного збору 
передбачалося у 2020 році у терміни, які кожна з країн учасниць визначала самостійно, проте пандемія COVID-19 викликала зміни у цілому ряді податкових механізмів.

Країни Свропи наполегливо намагаються подолати економічний вплив COVID-19, одночасно формуючи основу для майбутньої стабілізації. Для тих, хто є членами $€ C$, Європейська Комісія зобов'язується сприяти співпраці 3 державами-членами, щоб забезпечити своєчасне здійснення національних заходів фінансової підтримки та стимулів. Ряд європейських програм розроблені для того, щоб усунути обмеження грошового потоку, з якими стикаються багато приватних компаній, а особливо сфера гостинності та туризму.

Основним заходом, яких впроваджується у всіх країнах $Є С$ - це відтермінування податкових сплат, зниження ставки для платників ПДВ, субсидії на заробітну плату та збільшення можливостей для позик малому та середньому бізнесу. Станом на 01 червня 2020 року ряд країн СС вносили корективи в діючі ставки оподаткування та розробляли програми підтримки бізнесу.

Австрія. Створено фонд для ліквідації наслідків карантину для австрійських підприємств, на діяльність яких вплинула пандемія. Прогнозується, що ці фонди не будуть оподатковуватися податком на прибуток підприємств.

Данія. Податок на заробітну плату та внески на ринок праці відтерміновано попередньо на 4 місяці. У квітні 2020 року СС оголосив про затвердження спеціального компенсаційного фонду для оплати витрат туристичних та івент-компаніям, організаторам розважальних заходів, які були скасовані між 6 березня 2020 року та 31 березня 2020 року. Попри це, політика сприяння продовжується з 01 жовтня 2020 року.

Франція запровадила широкі фінансові заходи для підтримки французьких компаній, які зазнали серйозного впливу COVID-19. До цих заходів входять: відтермінування внесків на соціальне страхування та податків, а також тимчасове припинення оплати комунальних платежів та орендної плати для приватного бізнесу.

Німецькі урядові міністерства та державний банк ввели спеціальний план запобігання компаній від банкрутства через COVID-19. 3 метою заохочення надання комерційними банками позик з низькими відсотками компаніям, що зазнали значних збитків від пандемії та іiї наслідків, державний банк Німеччини KfW, пропонує покрити до 90 відсотків ризику без обмеження коштів, доступних для гарантій. План відкритий для всіх підприємств, які станом на 31 грудня 2019 року не стикалися з фінансовими проблемами. Розроблено додаткові програми економічної підтримки, які очікують на затвердження Європейською комісією. Тим часом запроваджуються варіанти відтермінування сплати податків та зменшення передоплати для покращення позицій грошових потоків компаній.

Ірландія на тлі складних торговельних умов призупинила стягнення відсоткових ставок за несвоєчасні виплати ПДВ на січень та лютий 2020 року, а зобов'язання „Платіж, як заробиш” (РАYЕ) на лютий та березень припинено. Усі сплати боргу в Ірландії призупинено до подальших інструкцій. Поточний статус податкового звільнення залишатиметься чинним для всіх підприємств.

Італія відтермінувала подання податкових декларацій до 30 червня 2020 року для компаній у сферах туризму, спорту, розваг, мистецтва, культури, освіти, транспорту, харчування та некомерційних організацій. Також вводяться податкові пільги до 20000 євро для витрат, пов'язаних із санітарними заходами [4, 5, 9].

Уряд Нідерландів оголосив, що підприємства, які стикаються 3 проблемами ліквідності внаслідок COVID-19, можуть подати заявку на відтермінування до з місяців ПДВ, податку на доходи фізичних осіб та корпорацій та податку на заробітну плату. Ті підприємства, які очікують щорічний спад продажів щонайменше на 20 відсотків, мають доступ до надзвичайного фонду для покриття частини витрат на заробітну плату. 
Крім того, підприємства, які були змушені тимчасово закритись, можуть мати право на компенсацію у розмірі 4000 євро. Рівні гарантій збільшуються за кількома гарантованими державою схемами позик для малого та середнього бізнесу.

Іспанія запровадила можливість відтермінування невеликих податкових боргів на державному рівні з простроченням, включаючи утримання податку на додану вартість, акцизи та податок на прибуток підприємств. Компанії отримають відстрочку на 6 місяців, без відсотків за прострочення платежів, що нараховуються протягом перших 3 місяців. Додаткова пропозиція дає можливість малому та середньому бізнесу гарантований державою кредит для зменшення втрат доходів, особливо для тих, хто займається туристичною галуззю.

Швеція запровадила субсидії на короткострокові відпустки, завдяки якій роботодавці можуть отримувати приблизно 90 відсотків витрат на заробітну плату працівникам, які скористались короткочасною відпусткою через COVID-19. Уряд також оплатить повну суму всіх витрат на лікарняні, понесені у квітні та травні 2020 року.

Швейцарія виділила 10 мільярдів швейцарських франків на підтримку компаній, які безпосередньо постраждали від пандемії. Окрім цього, передбачено 580 мільйонів швейцарських франків у вигляді банківських позик із гарантіями для малого та середнього бізнесу за зниженими відсотками.

Великобританія встановила нові гарантовані, підтримувані урядом, недорогі позики великим підприємствам та малому бізнесу для забезпечення потреб у ліквідності. 3 введенням нової схеми кредитування, малий та середній бізнес матиме доступ до позик на суму до 5 мільйонів фунтів стерлінгів, без сплати відсотків протягом перших 6 місяців. Впроваджується схема збереження робочих місць, згідно 3 якою державні дотації покриватимуть 80 відсотків заробітної плати утримуваних працівників, загалом до 2500 фунтів стерлінгів на місяць. Схема буде доступна для будь-якого роботодавця в країні мінімум 3 місяці для покриття витрат на заробітну плату, датовану датою 1 березня 2020 року. Наразі обмеження на доступне фінансування не існує. Окрім того, вдосконалюються заходи, про які було оголошено раніше. Наприклад, безвідсотковий період для схеми надання позик на карантинний період збільшено до 12 місяців; виплати ПДВ у 2 кварталі відкладено на середину червня 2020 року; підприємствам дозволено здійснювати податкові сплати до кінця фінансового року. Гранти для підприємств, які мають право на пільгу для малого бізнесу, збільшено до 10000 фунтів стерлінгів.

3 червня 2020 року Рада ЄС (офіційно) прийняла поправки до Директиви про адміністративне співробітництво, що дозволяють державам-членам відкласти на шість місяців строки подання та обміну наступною інформацією:

1) автоматичний обмін інформацією про фінансові рахунки, бенефіціарами яких $\epsilon$ податкові резиденти в іншій державі-члені (CRS / DAC2 - відстрочка на три місяці);

2) вимоги щодо обов'язкового розкриття інформації (MDR) для посередників та відповідних платників податків згідно (DAC6 - відстрочка на шість місяців) [8].

Директива Ради (СС) 2020/876 від 24 червня 2020 року (далі «Директива про відкладення DAC6»), набрала чинності 27 червня 2020 року. Зазначається можливість відтермінувати подання інформації про звітні транскордонні угоди на термін до шести місяців наступним чином:

1) до 28 лютого 2021 року (раніше 31 серпня 2020 року) щодо домовленостей, де перший крок був здійснений між 25 червня 2018 року та 30 червня 2020 року (так звані „історичні домовленості“).

2) дата початку 30-денного терміну звітування, який повинен розпочатися до 1 січня 2021 року (раніш 1 липня 2020 року). Це також застосовуватиметься до 
транскордонних домовленостей, щодо яких тригер звітування виникає у період 31 липня 2020 року до 31 грудня 2020 року.

Більшість держав-членів обрали шість місяців відстрочення подання звітності згідно з ЦАП6, за винятком Австрії (тримісячне продовження), Фінляндії та Німеччини (без відстрочки). Іспанія ще не завершила процес транспонування DAC6, а тому ще не в змозі застосовувати правила.

29 липня 2020 року юридичні документи, що відтермінують введення в дію пакету електронної комерції з ПДВ на шість місяців, були опубліковані в Офіційному віснику Свропейського Союзу, тобто правила застосовуватимуться з 1 липня 2021 року замість 1 січня 2021 року [7].

Відстрочення політики інформування не лише враховує сучасні кризові умови, а й дозволяє за цей період розробити уніфіковані механізми посткарантинного відновлення та розвитку.

Таким чином, регулятивна податкова політика $Є C$ щодо діяльності всіх економічних агентів носить гнучкий характер i направлена на збереження економічного середовища. Туристичній сфері на трьох рівнях податкової ієрархії створені максимальні умови для збереження і створені платформи для відновлення у майбутньому періоді.

Висновки. Глобальна економічна та соціальна турбулентність, спричинена пандемією COVID-2019 вплинула на всі сфери життя як країн та і цілого світу. Економічні, передбачувано стабільні системи довели неспроможність повноцінних ефективних реакції на неочікувані виклики. Країни, зі стійкою економічної системою, такі як більшість країн $\mathrm{CC}$, володіючи потужними фінансовими ресурсами показали спроможність реагувати на виклики i намагатися максимально підтримати життєдіяльність своїх підприємств. Зважаючи на те, що туристична сфера, яка набирала потужних обертів у своєму розвитку протягом останніх 10 років і яка постраждала найбільше у 2020 році, максимально підтримується у загальнонаціональних вимірах, проте представники малого бізнесу немережевого формату не у повному обсязі зможуть вийти повноцінними гравцями ринку у короткостроковій перспективі. Підсумовуючи, варто зазначити, що податкова політика Європейського Союзу, яка була активно скоординована протягом короткого періоду часу дозволила частково зняти напруження 3 бізнес-середовища і дала можливість поступової адаптації під виклики нового часу. Окреслена проблематика є новою для економічної сфери, тому потребує подальших грунтовних досліджень.

1. Ведение бизнеса с Европейским Союзом: руководство для начинающих экспортёров / Посольство Великобритании в Украине. 2014. С. 55.

2. Договір про заснування Свропейської Спільноти ( Договір про заснування Свропейського економічного співтовариства). URL: https://zakon.rada.gov.ua/laws/card/994_017 (дата звернення 15.10.2020).

3. Международные рекомендации по статистике туризма. OOH. 2008 . URL: https://unstats.un.org/unsd/tourism/publications/IRTS\%202008\%Compilation\%20Guide\%20(R).pdf3

4. Changes in the Law on Income Tax: KPMG. URL: https://home.kpmg/al/en/home/about/overview.html (дата звернення 15.10.2020).

5. Eurostat: European Commission URL: http://ec.europa.eu/prelex/detail_dossier_real. (дата звернення 15.10.2020).

6. Study on the review of the VAT Special Scheme for travel agents and options for reform / European Commission. URL: https://ec.europa.eu/taxation_customs/sites/taxation/files/travel_ agents_special_vat_scheme_en.pdf (дата звернення 15.10.2020).

7. Taxation and Customs Union Directorate General of the Commission (DG TAXUD). URL: https://ec.europa.eu/info/departments/taxation-and-customs-union_en (дата звернення 15.10.2020). 
Актуальні проблеми розвитку економіки регіону. Вип 16. T.2

8. Taxation trends in the European Union / General for Taxation and Customs Union (DG TAXUD) URL: https://ec.europa.eu/taxation_customs/sites/taxation/files/taxation_trends_report_2020.pdf (дата звернення 15.10.2020).

9. Tourist tax: European Union outlook. URL: https://europarup.com/tourist-tax-european-unionoutlook/ (дата звернення 15.10.2020).

10. Travel \& Tourism: Economic Impact 2017 European Union LCU. URL: https://www.slovenia.info/uploads/dokumenti/raziskave/europe2018.pdf $\quad$ (дата звернення 15.10.2020).

\title{
References
}

1. Doing Business with the European Union: A Guide for Beginning Exporters. British Embassy in Ukraine. 2014.

2. "Treaty on the Functioning of the European Union." Verkhovna Rada of Ukraine, zakon.rada.gov.ua/laws/card/994_017 Accessed 15 Oct.2020.

3. "International recommendations for tourism statistics." OON. 2008, unstats.un.org/unsd/tourism/publications/IRTS\%202008\%Compilation\%20Guide\%20(R).pdf3 Accessed 15 Oct.2020.

4. “Changes in the Law on Income Tax.” KPMG, Accessed 15 Oct.2020.

5. Eurostat: European Commission, ec.europa.eu/prelex/detail_dossier_real. Accessed 15 Oct.2020.

6. "Study on the review of the VAT Special Scheme for travel agents and options for reform." European Commission, ec.europa.eu/taxation_customs/sites/taxation/files/travel_ agents_special_vat_scheme_en.pdf Accessed 15 Oct.2020.

7. “Taxation and Customs Union Directorate General of the Commission (DG TAXUD)." European Commission, ec.europa.eu/info/departments/taxation-and-customs-union_en Accessed 15 Oct.2020.

8. "Taxation trends in the European Union / General for Taxation and Customs Union (DG TAXUD)" European

Commission, ec.europa.eu/taxation_customs/sites/taxation/files/taxation_trends_report_2020.pdf Accessed 15 Oct.2020.

9. “Tourist tax: European Union outlook.” europarup.com, europarup.com/tourist-tax-european-unionoutlook/ Accessed 15 Oct.2020.

10. "Travel \& Tourism: Economic Impact 2017 European Union LCU.” slovenia.info, www.slovenia.info/uploads/dokumenti/raziskave/europe2018.pdf Accessed 15 Oct.2020.

\section{УДК 339.74}

doi: 10.15330/apred.2.16.44-54

\section{МОДЕЛЮВАННЯ ТА ОЦІНКА ОСНОВНИХ ДЕТЕРМІНАНТІВ МІЖНАРОДНИХ РЕЗЕРВІВ В УКРАЇНІ \\ Грицишин $А$. T.}

\author{
Львівський національний університет \\ імені Івана Франка, \\ Міністерство освіти і науки України, \\ кафедра туризму, \\ вул. Університетська, 1, м. Львів, \\ 79000,Україна, \\ тел.: (032) 2394603 , \\ e-mail: anna.hrytsyshyn@lnu.edu.ua
}

Анотація. Стаття присвячена дослідженню процесу управління міжнародними резервами в України, зокрема, моделюванню основних детермінантів резервних активів в країні. На підставі аналізу емпіричних досліджень факторів впливу на обсяг та динаміку резервних активів виокремлено шість основних груп детермінантів міжнародних резервів, а саме: розмір та рівень розвитку економіки, поточний рахунок платіжного балансу, рахунок операцій 3 капіталом платіжного балансу, волатильність валютного курсу, альтернативна вартість зберігання міжнародних резервів та інституційні чинники. На основі вищезгаданої класифікації 